\title{
Linguo pragmatic features of speech acts "expression of refusals" in Russian and Uzbek languages
}

\section{Sayyora AZIMOVA ${ }^{1}$}

Fergana State University

\begin{tabular}{l} 
ARTICLE INFO \\
\hline Article history: \\
Received March 2021 \\
Received in revised form \\
20 March 2021 \\
Accepted 15 April 2021 \\
Available online \\
20 May 2021
\end{tabular}

Keywords:

linguistic-pragmatic,

speech acts,

dualism,

failure expression,

critical analysis,

pragmatic competence.

\begin{abstract}
This article will examine the theoretical features of speech acts against the background of criticism of structural linguistics and the consideration of the speech acts (SA) features in expression of refusals on the example of the Russian and Uzbek languages. Everyone knows that the linguistic pragmatic features of speech acts in the study of foreign languages: a critical theory of understanding the world is a very controversial, but also an interesting topic. We will try to reveal this topic. This article is specifically aimed at filling this scientific in terms of the study of pragmatics in the framework of speech acts.
\end{abstract}

2181-1415/CC 2021 in Science LLC.

This is an open access article under the Attribution 4.0 International (CC BY 4.0) license (https://creativecommons.org/licenses/by/4.0/deed.ru)

\section{Nutq harakatlarining lingvopragmatik xususiyatlarida "rad etish ifodasi" rus va o'zbek tillarida}

\footnotetext{
Kalit so'zlar:

lingvistik-pragmatik, nutq aktlari, dualizm, muvaffaqiyatsizlikni ifodalash, tanqidiy tahlil, pragmatik kompetensiya.
}

\begin{abstract}
ANNOTATSIYA
Ushbu maqola rus va o'zbek tillari misolida radikallarni ifodalagan holda tizimli lingvistikani tanqid qilish va nutqiy harakat (SA) va holatlarni hisobga olib, nutqining nazariy xususiyatlarini o'rganadi. Chet tillarni o'rganishda nutqning lingvistik pragmatik xususiyatlari katta rol o'ynashini hamma biladi: dunyoni anglashning tanqidiy nazariyasi juda ziddiyatli, va shu bilan birga ayni paytda qiziqarli mavzu. Biz ushbu mavzuni ochib berishga harakat qilamiz. Ushbu maqola ushbu ilmiyni nutq aktlari doirasida pragmatikani o'rganish nuqtai nazaridan to'ldirishga qaratilgan.
\end{abstract}

\footnotetext{
${ }^{1}$ Basic doctoral student, Fergana State University, Fergana, Uzbekistan.
} 


\section{Лингвопрагматические особенности речевых актов «выражение отказов» в русском и узбекском языках}

\author{
Ключевые слова: \\ лингвопрагматика, \\ речевые акты, \\ дуализм, \\ выражение неудач, \\ критический анализ, \\ прагматическая \\ компетентность.
}

\section{АННОТАЦИЯ}

В данной статье будут рассмотрены теоретические особенности речевых актов против предпосылки критики структурной лингвистики и учета особенностей речевых актов (PE) при выражении отказов на примере русского и узбекского языков. Всем известно, что лингвопрагматические особенности речи выступают при изучении иностранных языков: критическая теория познания мира - очень спорная, но тоже интересная тема. Постараемся раскрыть эту тему. Данная статья специально направлена на наполнение этой научной точки зрения прагматикой в рамках речевых актов.

One important area of pragmatics is that of speech acts, which are communicative acts that convey an intended language function. Speech acts include functions such as requests, apologies, suggestions, commands, offers, and appropriate responses to those acts. Of course, speakers of these acts are not truly successful until the intended meaning they convey are understood by listeners.

Speech acts occur in everyday talk in every society, with various ranges of explicitness. For second language learners, it is important to know which speech acts are different in the first and target language, how they are different, and what is not appropriate to say.

Speech act is a part of pragmatics where there are certain aims beyond the words or phrases when a speaker says something. Speech acts are acts that refer to the action performed by produced utterances. People can perform an action by saying something. Through speech acts, the speaker can convey physical action merely through words and phrases. The conveyed utterances are paramount to the actions performed. In regard to the English as a foreign language, there are things to consider. It is easy for the speakers or listeners to determine the intended meaning of utterances if they are spoken in the mother tongue. Factors such as idiomatic expressions and cultural norms are not function as barriers to determine the intended meaning.

Communication has always been a necessity in human life. Through communication, the trade of thought among people, which directly contributes to the development of the quality of life itself, can be performed. The ability to percept utterances in communication can determine the actions followed. Communication can be conveyed through verbal and nonverbal communication. Buck (2002) states that there are two types of communication, they are verbal and nonverbal communication. Verbal communication is the way of communicating messages by using words as elements. Nonverbal communication is the way of communicating messages by using gesture, body movements, eye contact, facial expression, or general appearances as the elements.

Pragmatics is a study which belief is what is communicated is more than what is said. The utterances that the speakers produce in communication contain deeper sense than the actual meaning of the words or phrases themselves. Yule (1996: 3) states that pragmatics has consequently more to do with the analysis of what people mean by their utterances than what the words or phrases in those utterances might mean by themselves. Pragmatics also strongly related with context or situation when something is being said, thus it is very important for the speakers to focus on the context. Leech (983: 6) also states that pragmatics is the study of meaning which is 
related to the speech situations. In accordance to Leech statement, Yule (1996) argues that pragmatics should also consider aspects of context such as who people are talking to, when, where, and under what circumstances that will determine the way they say and what they want to say.

Yule (1996: 3) states that there are four areas which pragmatics is concerned with:

1. Pragmatics is the study of speaker meaning.

2. Pragmatics is the study of contextual meaning.

3. Pragmatics is the study of how to get more communicated than it is said.

4. Pragmatics is the study of the expression of relative distance.

In the broad sense, through pragmatics we must be able to grasp the message of the utterances by being aware that the words or phrases contain deeper meaning than literal meaning of what is spoken. In line with this, Richard and Schmidt (2002) argue that pragmatics is the study of the use of language in communication related to sentences and the context and situations in which they are used. In the scope of pragmatics, there are some factors that should be considered. These factors establish the very definition of pragmatics itself. The factors are Implicature, Speech Acts, Presupposition, Context, Adjacency Pairs, and Deixis and Distance.

Speech act, a variety of verbal communication and also a subdivision of pragmatics, often takes place in verbal and nonverbal communication. Yule (1996) states that speech acts are a study of how the speakers and hearers use language. Bach (1979) explains that an action in verbal communication has message in itself, so the communication is not only about language but also with action. In conclusion speech act is the utterance that occurs and act refers to an action.

There are certain aims beyond the words or phrases when a speaker says something. Austin (in Tsui, 1994: 4) explains that speech acts are acts that refer to the action performed by produced utterances. In line with this, Yule (1996: 47) states that speech acts is action which is performed via utterances. Stating the same idea, Birner (2013) also says that uttering something means doing something. Here, people can perform an action by saying something. Through speech acts, the speaker can convey physical action merely through words and phrases. The conveyed utterances are paramount to the actions performed.

The theory of speech acts is the center of pragmalinguistics. Under the speech act refers to the statement posed and spoken with a purpose and having a particular motive to carry out practical or mental (as typically addressed) the action, using a tool such as language/ speech.

Speech act is a unity of the following components: 1) locutionary act - the utterance of the Message, Locutionary speech act is roughly equivalent to uttering certain utterance with certain sense and reference, which again is roughly equivalent to meaning in traditional sense (Austin, 1962: 108); 2) illocutionary act - an action in the process of pronouncing, The illocutionary act is performed via the communicative force of an utterance, such as promising, apologizing, offering (Yule, 1996: 48). This act is also called the act of doing something in saying something. The most significant level of action in a speech act is the illocutionary act because the force, which has been desired by the speakers, determines this act. 3) perlocutionary act - the exercise of influence on the addressee. Perlocutionary act is also the act offering someone. Perlocutionary act refers to the effect the utterance has on the thoughts or actions of the other person. A perlocutionary act is specific to the circumstances of issuance, and is therefore not conventionally achieved just by uttering that particular utterance, and includes all those effects, intended or unintended, often indeterminate, that some particular utterance in a particular situation cause. Making a speech act, the speaker simultaneously performs actions. The statement has not only the communicative aspect but also influencing effect on the listener (Ostin 1986. PP. 22-131). 
The system of speech acts proposed by J. Searle and D. Vandervecken included the following classes: assertives or representatives - represent the state of affairs, describe the reality; directives - serve as motivations for the commission of some act; commissives - impose certain obligations on the speaker; declarations - express "institutional", ritualized actions; expressives - serve for the expression of assessments and emotions, descriptions of the subjective picture of the world of the speaker (Searle and Vanderveken 1985. PP. 12-20).

Communicative and cognitive approach, developed since the end of the last century anniversary, characterized by the fact that the cognitive part is due to its direction to fix and store structures of knowledge and assessing the world in various linguistic forms, and its communicative part is focused on more on the features of these linguistic forms when used in communicative purposes. In other words, as notes N.N. Boldyrev, "the act of communication is is, on the one hand, the expression any thoughts with the help of language, that is generation of statements, and on the other hand us - understanding what others are saying, then have an understanding of their thoughts expressed in linguistic form. In both cases, we rely we focus on knowledge as a language (knowledge of grammar matics, lexical semantics, types of speech use) and extra-lingual properties (knowledge of the context, situation, background knowledge of the types of events, states, action events, processes, etc.). All this knowledge is co-put a common database that lie the basis of the functioning of the language and are connected with general processes of understanding, storage and transmission of information". Within this approach, special attention is paid to the study emotionally expressive utterances indirect and implicit refusal.

Emotionally expressive utterances refusal statements are expressed with the help of interjection statements.

Sometimes an offer will have to be politely rejected, albeit politely. In such cases, it is done using these expressions to politely reject the offer. We know that in almost all languages there is no denial in Uzbek "yo'q" Rather than say "no", give a reason why you want to reject the offer. Reject politely and thoughtfully so the speech turns out nicely.

Rahmat, lekin ...

Bu juda mehribon. Afsuski, men ...

Men xohlayman, lekin ...

Examples of the use of polite rejection in dialogue include the following in Uzbek language.

Along with the use of true significant interjections revealed cases use to implement indirect refusal unambiguous. Let's take an example:

- Пойдем со мной жениться.

Глаза Феди округлились.

- Не жениться, то есть сватать, - поправился Кузьма. - Я один что-то трушу.

- Ха! - Федя остановился. - А к кому?

- К Поповым (В. Шукшин).

Addressee responding negatively to a request Kuzma go woo together, uses exclamation point ha! rejection, which Fedya accompanies interrogative sentence And to whom? as if interested, thereby smoothing the sharpness of their negative reaction.

In Uzbek, the word denial is usually used to refer to the denial of anything that one seems unworthy. This is not limited to the rejection itself, but implies a mental descent of the rejected person, action, idea, or thing. What is rejected leads to shame and disgrace.

Rejection can be expressed in a variety of ways, either through organized civic action, in a context of debate, in the presentation of a personal opinion, or in a spontaneous collective action. Let's look at examples for each case: 
Oilalar hukumat saroyi oldida immigratsiya siyosatini rad etish uchun norozilik bildirmoqda. "Hokimiyatning axloqsiz xatti-harakatlari yaxshi odamlarning rad javobiga loyiqdir". "Men xalqni bo'ysundirmoqchi bo'lganlarning ikki tomonlama standartlarini rad etaman". "Odamlar uning xatti-harakatlaridan shunchalik g'azablandilar, ular o'yin o'rtasida uni bo'g'ib qo'yishdi".

M1: у тебя есть моя фотка?

И15: боже упаси

// М1: сфоткай меня

// М2: нет бл*дь

И15: давай быстрей

// M1: давай / сфоткай /

/ М2: да и чёрт с ним /

/ 9 2) М2: купи мне

// M1: нет //

(2) cadets from the environment (within the framework of the "speech day") I15 conduct their own conversations. 10 In the context of (1), the speaker's RA (M1) is a direct request (take a picture of me), and the listener's RA (M2) is a categorical refusal (no), with the addition of an unprintable expression. M1 repeats his request (come on / take a picture), which is supported by I15 (come on quickly). 11 In the context of (2), the speaker's RA (M2) is also a direct request (buy me) (we are talking about cigarettes), and the listener's RA (M1) is again a categorical refusal (no), without any options. 12 In both cases, the speakers (M1 and M2) are not at all surprised by the refusal. In example (1) the interlocutor (M2) nevertheless agrees to fulfill the request (and to hell with him); in example (2) the speaker calmly changes the topic of conversation: on / you can pick up (apparently, a finished photograph).

In Uzbek grammar, denial means that nothing exists or that no action is taken. Rejection of the above is the usual negative "yo'q". For example: "Men Mariananing tug'ilgan kunini nishonlashga bormayman" "Meni omonat hisobimda boshqa pul yoq", "Men bu haqida biror bir so'z aytmadim" It is common to be made up of words like Hech qachon (Men bu bolani hech qachon urmaganman) or Hech narsa (Munosabatlar mening hayotimda hech narsa qoldirmadi). Here the phrase implies a firm rejection.

There are also negative phrases in Uzbek, such as "kerak emas", "shart emas", "hojati yo'q", which are simply a one-time refusal.

M1: сейчас я дам чемо... // у меня вот / к... О длинный провод есть / я покажу и О одну секундочку // давай сначала одно / О Лёнечка сначала //

И38: нет / у тебя там с дамами что-то надо улаживать / улаживай //

M1: да нет ничего не надо // да не надо / они просто... /

И38: держи его уже ты // чего мне... чего мне на него смотреть?

M1: давай-ка я лучше / а вот как ты включил / одну секундочку / вот я...

In example (6), a conversation between a computer engineer (I38) and his acquaintance (M1) takes place at M1's home, whom I38 helps with mastering computer programs. In the example, you can see two refusal microdialogues at once, containing the word no. In the first case (a) RAG (M1) is a request-proposal to act in a certain way (give one first). In response, (RAS) I38 categorically says no and moves the conversation to another topic. As a result, a new (b) RAG (I38) appears - a very persistent advice: you have to settle something with the ladies there. RAS (M1) multiple, but soft refusal: yes, no, nothing is needed // yes, no need, which M1 will even try to explain and comment on (they just ...), but cuts itself off and returns the conversation to the 
computer. I38 is also not in the mood to continue the topic of ladies, which arose spontaneously, in the communication of close friends. Here we are dealing, rather, even with the RA not of a refusal, but of objections (close to refusal): the interlocutor, pronouncing a reply yes no, nothing is needed // yes, no, not so much refuses to settle something with the ladies, as he objects that he generally needs to settle something with them. One way or another, but the relations of the speakers are symmetrical, there is no obvious dominance.

Thus, both in Russian and in Uzbek speech culture for expression indirect and implicit statements refusal can be used such emotionally expressive statements as interjective statements, rhetorical questions, ironic statements. It should also be noted that for the implementation of indirect refusal, interjection statements and rhetorical questions appear, and implicit refusal statements are expressed in turn, also with interjections and ironic statements.

\section{REFERENCES}

1. Altman R. 1990. Giving and Taking Advice without Offence. New York: Newburry House.

2. Austin J.L. 1962. How to Do Things with Words. Oxford: Oxford University Press.

3. Bach K. and R.M. Harnish. 1979. Linguistic Communication and Speech Acts, Cambridge, Mass: MIT Press.

4. Blum-Kulka S., House J., \& Kasper G. 1989. Cross Cultural Pragmatics: Request and Apologies. Norwood, NJ: Ablex.

5. Buck R and Vanlear C. Arthur. 2002. Verbal and Nonverbal Communication: Distinguishing Symbolic, Spontaneous, and Pseudo-Spontaneous.

6. Nonverbal Behavior. Journal of Communication. 15, 522-528. Retrieved November12, 2012.

7. Cutting J. 2002. Pragmatics and Discourse. London: Routledge. Publications.

8. Fujimori. John. 2004. Practical Criteria for Teaching Speech Acts. Tokyo: JALT

9. Hymes D. 1974. Foundations of Sociolinguistics: An Ethnographic Approach. Philadelphia.

10. Isnaniah .2015. An Analysis of Speech Acts by Woody Pride in the movie Toy Story 3. English Education Department. Faculty of Tarbiyah and Teachers Training. Unpublished Thesis.

11. Leech G. 1996. Principles of Pragmatics. New York: Longman.

12. Searle J.R. 2005. Expression and Meaning: Studies in the Theory of Speech Acts. Cambridge: Cambridge University Press.

13. Yule G. 1996. Pragmatics. Oxford: Oxford University Press. 